\title{
Comparison of Stern Wedge and Stern Flap on Fast Monohull Vessel Resistance
}

\author{
Edi Jadmiko ${ }^{1}$, Irfan Syarif ${ }^{2}$, Lukman Arif ${ }^{3}$
}

\begin{abstract}
Ship resistance is main factors that can give more effect the design of a ship. In studies do it with a design modification of the stern form. The addition of stern design to establish Stern flaps and Stern wedge that will be affect the value of resistance and flow patterns sistem that follow in the stern so that the resistance will be smaller. In this final project will be reseach about resistance on the stern at Barehull shape, and with the addition of Stern flaps or Stern wedge with variations of chord length and chord angle. The focus of this reseach is reduction in ship resistance generated when the ship operates with stern flaps or stern wedges. The simulation is done by Computational Fluid Dynamics (CFD) method using NUMECA Fine Marine software. The results of the analysis can be seen in the addition of the stern and flow patterns sistem that follow. Based on the result of simulation, the most optimal stern form performance reduces the resistance is Stern flap $1 \%$ Lpp with angle $4^{\circ}$. The resistance value is reduced to $9.33 \mathrm{kN}$ or $3.5 \%$ at 28 knots.
\end{abstract}

Keywords-CFD, Chord, Ship Resistance, Speed, Barehull, Stern, Stern flaps, Stern wedge.

\section{Introduction ${ }^{1}$}

\section{$\mathrm{R}$} esistance is a main factor that can be considered in the design of a ship. Basicaly shiphull cultivated forms are made as efficient as possible, so that the power requirements to drive the ship could be in could value as small as possible [1]. The effort to keep the small ship's resistance is done with proper design on the hydrodynamics and propulsion such as changing the stern shape into a tunnel [2] or the additional energy savng device in propulsion system such as propeller boss cap fin [3]. On the stern generally, when ship sailing will be found less efficient stream patterns. This is because before the stern flap the flow velocity under the stern of the stern high and the low lifting force, resulting in a previous study of stern flaps with variation of chord width [4], that the effect of stern flaps can reduce resistance to $3 \%$ of total resistance, as well as to alter the flow of water around the stern by increasing the outflow velocity on the trailing edge compared to ships without flap.

Stern wedge is capable of reduce the resistance up to $20 \%$ when the ship at high speed [4]. So that will be done the comparison of resistance that are produced, is expected the stern shape can decrease resistance.

In this study discusses ship resistance and flow patterns due to changes in the shape of the ship's stern. To get the value of ship resistance and flow patterns that occur due to changes in shape of the stern, then analyzed the approach of using CFDNUMECA FineMarine software. When the stern ship section with a variation of the chord

Edi Jadmiko, Departmen of Marine Engineering, Institut Teknologi Sepuluh Nopember, Surabaya 60111, Indonesia,

Email : gusjadmiko@gmail.com

Irfan Syarief, Departmen of Marine Engineering, Institut Teknologi Sepuluh Nopember, Surabaya 60111, Indonesia,

Email : irfansya@gmail.com

Lukman Arif, Departmen of Marine Engineering, Institut Teknologi Sepuluh Nopember, Surabaya 60111, Indonesia,

Email : lukmanarif051@gmail.com angle and chord length of each form stern flaps and wedge.

\section{RESEARCH METHODOLOGY}

The methodology used in the study is a simulation based-method, which will be used as a reference for solving problems. This thesis writing methodology covers all the questions that will be solved out to solve the problem or do the analysis process to the final task problem. More details be described as follows:

\section{A. Waterflow stern ship phenomenom}

Phenomenon of flow at stern ship is the flow that follows the motion of the ship (wake fraction). Wake fraction is difference of velocity the vessel with the speed of water through the propeller. The phenomenon occurs at stern of ship due to changes ii of the flow produced by the front of ship. Then selected of stern hull shape effect on the flow of water in the stern, the determination of the stern hull shape impact on the magnitude of the value of ship resistance. As for the form of stern flaps and stern wedge on the ship can reduce viscous pressure resistance [5].

\section{B. Stern Flaps}

An additional part of hull is used to reduce resistance that occurs on ship. The decreaseable betwen $1-10 \%$ of the total ship resistance. Stern flap is located at the stern of the ship. The interaction with the hull takes place on the trim of the vessel, reducing the propulsion resistance and increasing the speed. Several studies regarding stern flaps has been conducted and came up with various results. The resistance reduction varied from $3.4 \%$ [6] untul 8.2\% [8].The most important parameters of stern flap is length of chord (Lf), the flap angle $(\alpha)$ and flap span along the transom. All stern flaps depend on the size and type of the ship to be used. [2]

Stern flap causes lift force on transom and changes the pressure distribution at stern. Resistance existing vessel effect on trim angle $4^{0}-5^{0}$. While on the stern flap displacement hull results in a trim angle increment of $0.1-0.3^{0}$. The basic advantage of the ship with the addition of a stern flap on the ship is the change in the flow pattern at stern. This stream provides a drag reduction at stern and changes wave resistance on ship. [2] 
Basic advantages of adding a stern flap:

- Reduce resistance during powering

- Increases maximum speed
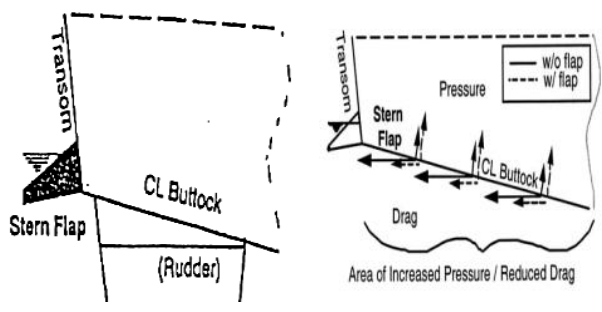

$a$

Figure 2. (a) Stern flaps (b) Stern flaps Location

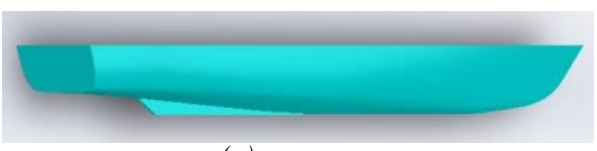

(a)

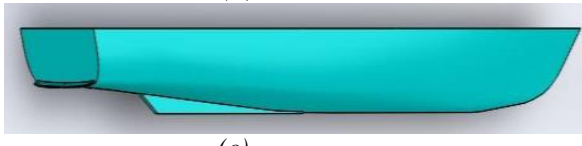

(c)

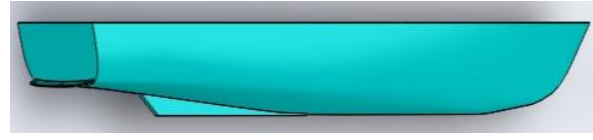

(e)

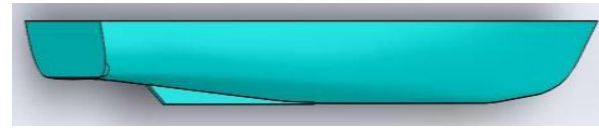

$(g)$
- Changing the flow pattern of water passing through transom.

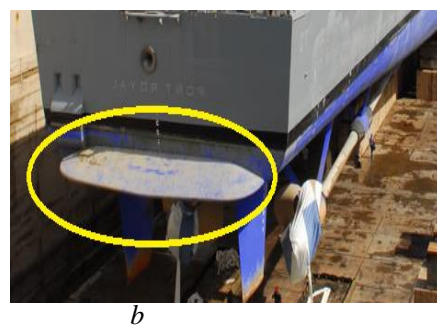

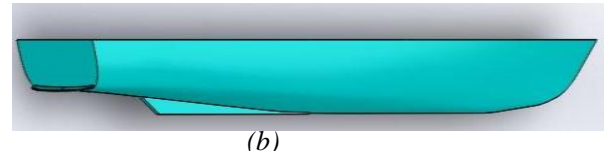

(b)

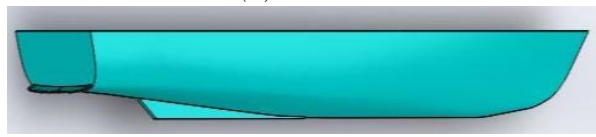

(d)

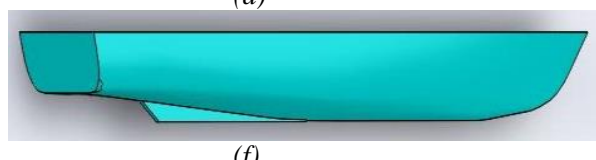

(f)

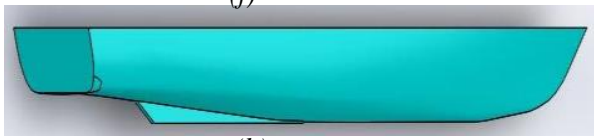

$(h)$

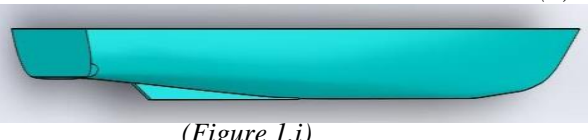

Figure 1. (a) Barehull (b) With Stern flaps $1 \%$ Lpp and $4^{0}$ angle (c) With Stern flaps $1 \%$ Lpp and $8^{0}$ angle (d) With Stern flaps $1.5 \%$ Lpp and $4^{0}$ angle (e) With Stern flaps $1.5 \%$ Lpp and $8^{\circ}$ angle (f) With Stern wedge $1 \%$ Lpp and $4^{0}$ angle (g) With wedge flaps $1 \%$ Lpp and $8^{0}$ angle (h) With Stern wedge $1.5 \% \mathrm{Lpp}$ and $4^{\circ}$ angle (i) With Stern wedge $1.5 \% \mathrm{Lpp}$ and $8^{\circ}$ angle

Stern flap causes the lower flow of the hull to decrease at the location of the addition of length. Decrease in flow velocity will increase the pressure on the bottom of the hull, causing a reduction in the afterbody suction force (reduction of the drag shape). The wave height and wave energy at the stern can be reduced in the presence of a stern flap. [4]

Based on the reference use stern flaps there are some configuration. The curvature around the ship's hull radius. In some cases, it is found the width of the span is approximately half the width of the transom configuration is based on test results for US Navy military ships. In the configuration it is recommended that in designing the stern flap in the following range [8]:

- Chords between 0.5 to $2.5 \%$ LPP.

- The angle of stern flap between $0^{\circ}$ (negative angle) to $20^{\circ}$.

- The span wide the maximum width across the transom, so it does not affect the angular shape and requires no

\section{Hydrodynamic effect of Stern flaps}

Use of stern flaps can alter the flow pattern and hydrodynamic, the effect that occurs due to the addition of stern flaps:

1. Change waterflow on stern
Decrease flow rate and increases the dynamic pressure under the hull. Increased pressure area causes a greater lifting force and effect postitive movement direction of the ship. Stern flaps increase the flow rate out on the trailing edge compared to the transom without flap. This speed increase will reduce the flow separation and makes the flow more steady and reduce viscous pressure resistance.

2. Change wave system

The transfer of flow around the stern area without a stern flap is caused loss of eddy-making energy, turbulence and white water. At the same velocity the stern flap resulted in the flow area by reducing the height, the slope and the wave breaking. With the stern flap can reduce the wave height in the system area on stern.

3. Lift and Drag

Stern flap can produce lift and drag style. The advantages are interaction with the hull and propeller so as to reduce the ship's resistance. Lifting and drag lifting increases with the chord, span and angle increases from the stern flap. [6]

\section{Stern Wedge}


Stern wedges are installed at the end of the stern of the ship, just below the transom. The main principle underlying the installation of stern wedges is to improve the flow patterns of water that occur in the stern of the ship so that later influential on the efficiency of the propulsion system.

Stern wadges is a modified form of the ship at the stern of the ship precisely between stations 19.5 - 20 or below transom. The stern wedge angle can be measured relative to the stern line. The front edge of the wedge is made as the 'embedded' curve of the stern hull surface and the Stern wedges mounted at the bottom of the stern hull of the submerged vessel just below the transom, made between the relative wedge angle $0^{0}-10^{0}$ from the hull surface, the length of the $2 \%$ stern wedges is Length of perpandicular. Stern wedges mounted at the end of the

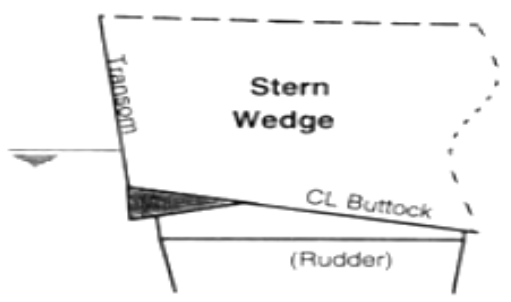

(a)

Figure 3. (a) Stern wedge (b) Stern wedge Location

\section{ANALYSIS AND DISCUSSION}

\section{A. Simulation Process Using CFD software}

CFD is a numerical analysis method used to solve fluid dynamics problems. Since the great advances in computer performance, CFD method is used to solve the Reynolds Averaged Navier-Stokes (RANS) equations that have been applied to different types of sternThere are several processes performed in CFD method. As for the process in CFD there are 3 parts:

- Pre-Processor

The initial stage in Computational Fluid Dynamic (CFD) which is the stage of data input that includes the determination of domain and boundary conditions. At this stage meshing is also done, where the analyzed object is divided in the number of specific grids.

- Processor

The next stage is stage processor, where at this stage is done data calculation process that has been entered using related equation iteratively until the results

COMPARISON BAREHULL RESISTANCE WITH STERN FLAPS $1 \%$ LPP $4^{0}$

\begin{tabular}{cccccc}
\hline No & $\begin{array}{c}\text { Speed } \\
(\mathrm{knot})\end{array}$ & $\begin{array}{c}\text { Froude } \\
\text { Number }\end{array}$ & $\begin{array}{c}\text { Barehull } \\
(\mathrm{kN})\end{array}$ & $\begin{array}{c}\text { Resistance } \\
\text { Stern Flap 1\%Lpp 40 } \\
(\mathrm{kN})\end{array}$ & $\begin{array}{c}\text { Difference } \\
(\%)\end{array}$ \\
\hline 1. & 12 & 0.2658 & 62.88 & 63.05 & $-0.3 \%$ \\
2. & 16 & 0.3545 & 96.72 & 94.01 & $2.8 \%$ \\
3. & 20 & 0.4431 & 157.17 & 152.18 & $3.2 \%$ \\
4. & 24 & 0.5317 & 215.38 & 208.72 & $3.1 \%$ \\
5. & 28 & 0.6203 & 266.42 & 257.92 & $3.2 \%$ \\
\hline
\end{tabular}

The difference in resistance occurring due to stern flaps $1 \%$ Lpp angle $4^{0}$ decreased significantly. At speed 28 knots decreasing to $8.5 \mathrm{kN}$, but the speed of 12 knots resistance was up $0.17 \mathrm{kN}$. The flow pattern that passes through the stern flap undergoes changes stern of the ship, just below the transom. The underlying principle is the installation of stern wedges to repair water flow patterns which occur in stern ship thus affecting the efficiency of the propulsion system.

Like stern flaps, the stern wedges have functions similar to stern flaps. Stern wedges are an additional part of the hull that is used to reduce the ships' vessels. The amount of resistance that can be reduced is about $1-10 \%$ of the total ship resistance. Stern wedges are located at the stern of the ship and under transom. The interaction with the hull takes place on the trim of the vessel, reducing the propulsion resistance and improving it to the ship's velocity. The most important parameters of the stern wedges are the length of the chord (Lf), the wedges angle $(\alpha)$ and theflap span along the transom. [4]

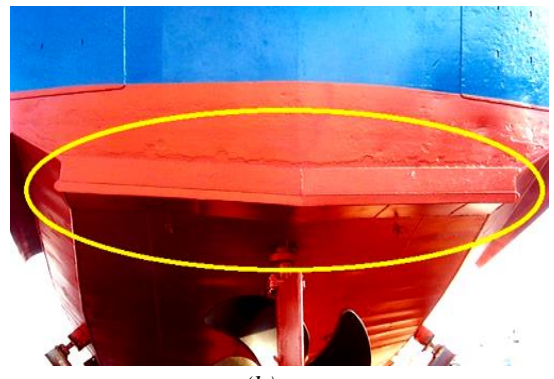

b)

obtained can reach the smallest error value.

\section{- Post Processor}

The last stage is the post processor stage, the results of the calculations at the stage of the processor will be displayed in pictures, graphics and animations.

\section{B. Simulation Result}

From the model simulation results in get the value of resistance on the ship model needed for analysis compare resistance values generated barehull models and with ship models with stern flaps or stern wedge. And the analysis of the model and selected the most optimal model. Of the 9 existing models and after the simulation by giving each 5 variations then the data obtained simulation results as much as 45 data, 8 table of comparison. Simulation result of the model.

1. Resistance difference Barehull with Stern Flaps 1\% Lpp $4^{0}$

Result of simulation of resistance at stern flaps with Length $1 \% \operatorname{Lpp~} 4^{0}$ angle: in flow shape and velocity, the flow of water in which the barehull model has a decayed water flow pattern at the stern of the ship. After stern flaps flow pattern becomes elongated and direction becomes to the bottom as shown. 


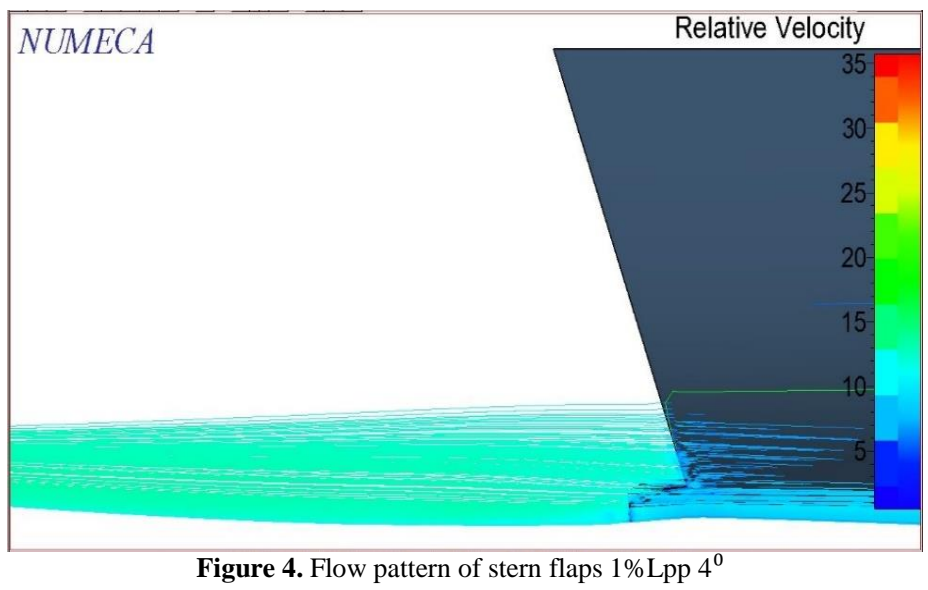

2. Resistance difference barehull with Stern flaps $1 \%$ Lpp $8^{0}$
Result of simulation of resistance at stern flaps with Length of $1 \%$ Lpp angle $8^{0}$ :

TABLE 2

COMPARISON BAREHULL RESISTANCE WITH STERN FLAPS1 \% LPP $8^{0}$

\begin{tabular}{|c|c|c|c|c|c|}
\hline \multirow[b]{2}{*}{ No } & \multirow[b]{2}{*}{$\begin{array}{l}\text { Speed } \\
\text { (knot) }\end{array}$} & \multicolumn{4}{|c|}{ Resistance } \\
\hline & & $\begin{array}{l}\text { Froude } \\
\text { Number }\end{array}$ & $\begin{array}{l}\text { Barehull } \\
(\mathrm{kN})\end{array}$ & $\begin{array}{c}\text { Stern Flap } 1 \% \text { Lpp } \\
8^{0} \\
(\mathrm{kN})\end{array}$ & $\begin{array}{c}\text { Difference } \\
(\%)\end{array}$ \\
\hline 1. & 12 & 0.2658 & 62.88 & 63.46 & $-0.9 \%$ \\
\hline 2. & 16 & 0.3545 & 96.72 & 95.79 & $1.0 \%$ \\
\hline 3. & 20 & 0.4431 & 157.17 & 154.31 & $1.8 \%$ \\
\hline 4. & 24 & 0.5317 & 215.38 & 210.79 & $2.1 \%$ \\
\hline 5. & 28 & 0.6203 & 266.42 & 260.11 & $2.4 \%$ \\
\hline
\end{tabular}

The difference in the number of occurrences caused by stern flaps $1 \%$ Lpp angle $8^{0}$ decreased, the decrease in resistance in stern flaps is no better than before. At speed of 12 knots ship resistance was up 1 $\mathrm{kN}$, when the speed of $16-28$ knots ship resistance decreased between $1 \mathrm{kN}-6.3 \mathrm{kN}$. The presence of stern flaps causes the flow pattern to be elongated

and the direction of flow to be downward as in the figure, the direction of the flow is deeper than the flow pattern in the stern flaps model angle $4^{0}$. Maybe so late when the ship cruised at low speed will experience additional obstacles. Figure simulation flow pattern and wave height 28 knots speed:

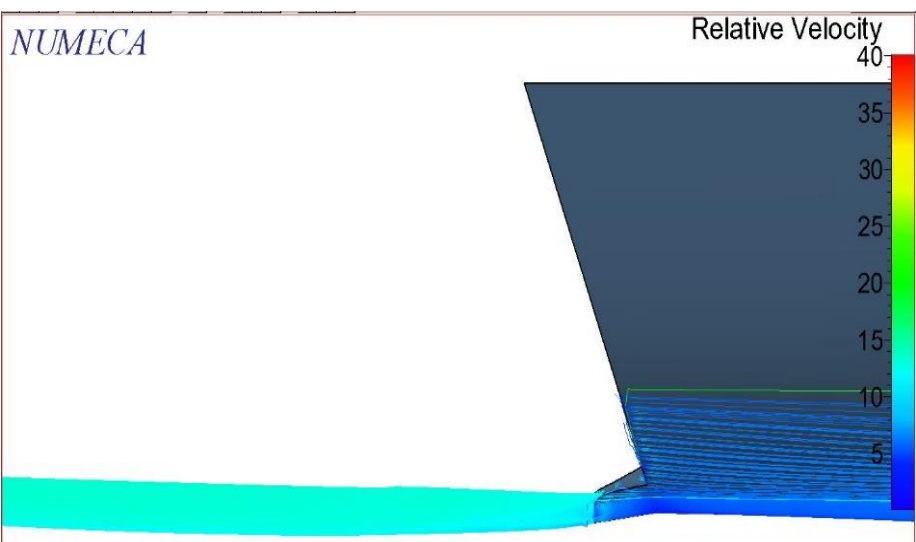

Figure 5. Flow pattern of stern flaps $1 \% \operatorname{Lpp} 8^{0}$

3. Resistance difference barehull with Stern flaps $1.5 \%$ $\operatorname{Lpp} 4^{0}$
Results of simulation of stern flaps resistance $1.5 \%$ Lpp angle $4^{0}$ :

TABLE 3.

COMPARISON BAREHULL RESISTANCE WITH STERN FLAPS $1.5 \%$ LPP $^{0}$

\begin{tabular}{cccccc}
\hline No & $\begin{array}{c}\text { Speed } \\
(\mathrm{knot})\end{array}$ & $\begin{array}{c}\text { Froude } \\
\text { Number }\end{array}$ & $\begin{array}{c}\text { Rarehull } \\
(\mathrm{kN})\end{array}$ & $\begin{array}{c}\text { Stern Flap 1,5\%Lpp } \\
4^{0} \\
(\mathrm{kN})\end{array}$ & $\begin{array}{c}\text { Difference } \\
(\%)\end{array}$ \\
\hline 1. & 12 & 0.2658 & 62.88 & 62.80 & $0.1 \%$ \\
2. & 16 & 0.3545 & 96.72 & 94.05 & $2.8 \%$ \\
3. & 20 & 0.4431 & 157.17 & 152.27 & $3.1 \%$ \\
4. & 24 & 0.5317 & 215.38 & 208.42 & $3.2 \%$ \\
5. & 28 & 0.6203 & 266.42 & 257.09 & $3.5 \%$ \\
\hline
\end{tabular}


From the table describe that the resistance caused by stern flaps $1.5 \%$ Lpp $4^{0}$ angle decreased signifi cantly, betwen 0.08 to $9.33 \mathrm{kN}$ at speed of 12 to 28 knots. It means that the stern flaps of resistance will be reduced. Here's a picture of simulation result of flow pattern and wave height at speed 28 knot:

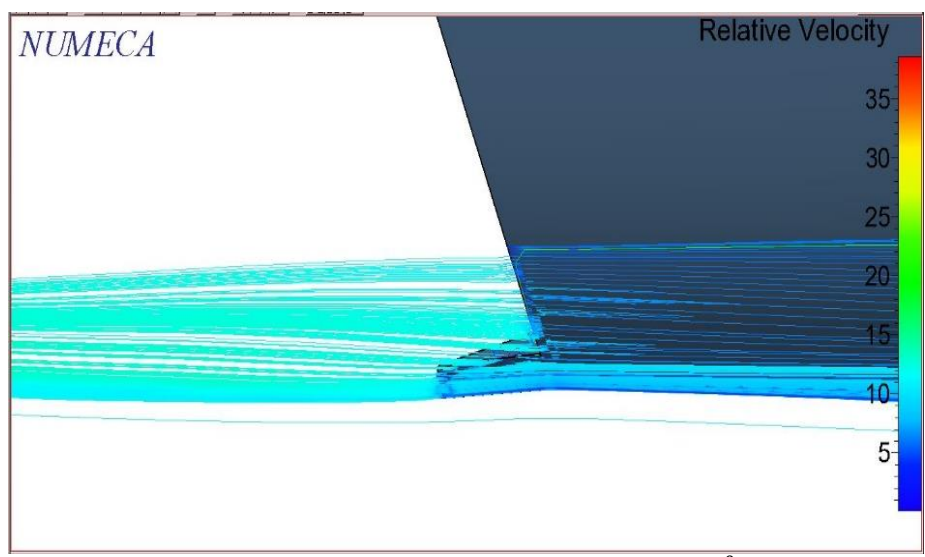

Figure 6. Flow pattern of stern flaps 1,5\% Lpp $4^{0}$

With the addition of stern shape, it can lower the resistance. The decline is caused by the increase of $p$ gathering is the water flow in ship (stern). Extra length is resulting in increased of area force lift. So, it has decreased trim angle.
4. Resistance difference barehull with Stern flaps $1.5 \%$ Lpp $8^{0}$

The result of simulation of resistance at stern flaps $1.5 \% \mathrm{Lpp} 8^{\circ}$ angle, as follows:

TABLE 4.

COMPARISON BAREHULL RESISTANCE WITH STERN FLAPS $1.5 \%$ LPP 8

\begin{tabular}{|c|c|c|c|c|c|}
\hline \multirow[b]{2}{*}{ No } & \multirow[b]{2}{*}{$\begin{array}{l}\text { Speed } \\
\text { (knot) }\end{array}$} & \multicolumn{4}{|c|}{ Resistance } \\
\hline & & $\begin{array}{l}\text { Froude } \\
\text { Number }\end{array}$ & $\begin{array}{c}\text { Barehull } \\
(\mathrm{kN})\end{array}$ & $\begin{array}{c}\text { Stern Flap } 1,5 \% \text { Lpp } \\
4^{0} \\
(\mathrm{kN})\end{array}$ & $\begin{array}{c}\text { Difference } \\
(\%)\end{array}$ \\
\hline 1. & 12 & 0.2658 & 62.88 & 64.95 & $-3.3 \%$ \\
\hline 2. & 16 & 0.3545 & 96.72 & 96.91 & $-0.2 \%$ \\
\hline 3. & 20 & 0.4431 & 157.17 & 155.42 & $1.1 \%$ \\
\hline 4. & 24 & 0.5317 & 215.38 & 212.14 & $1.5 \%$ \\
\hline 5. & 28 & 0.6203 & 266.42 & 261.82 & $1.7 \%$ \\
\hline
\end{tabular}

These data, indicat the resistance that occur due to stern flaps $1.5 \%$ Lpp $8^{\circ}$ angle decreased, decrease occurred at high speed. Decrease between 2.6 - 4.6 $\mathrm{kN}$. Figure of simulation results flow patterns and high waves at a speed of 28 knots menunjuukan that stern flaps which have a higher angle will result into obstacles at low speeds and will reduce the resistance at high speed, as shown below:

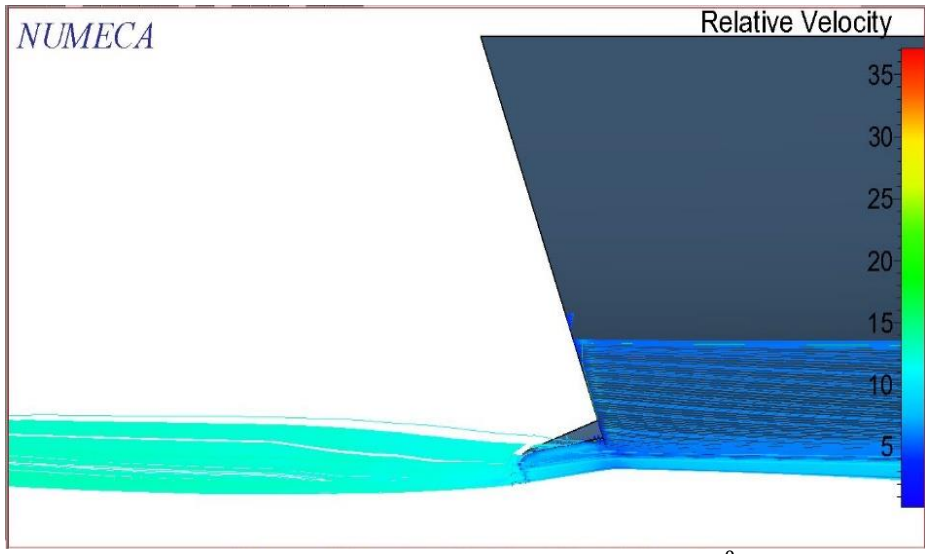

Figure 7. Flow pattern of stern flaps $1,5 \% \mathrm{Lpp} 8^{0}$

5. Resistance difference barehull with Stern wedge $1 \% \operatorname{Lpp} 4^{0}$
Results of simulation barrier stern wedge $1 \% \mathrm{Lpp}$ $4^{0}$ angle:

TABLE 5.

COMPARISON BAREHULL RESISTANCE WITH STERN WEDGE $1 \%$ LPP $4^{\circ}$

\begin{tabular}{cccccc}
\hline No & $\begin{array}{c}\text { Speed } \\
(\mathrm{knot})\end{array}$ & $\begin{array}{c}\text { Froude } \\
\text { Number }\end{array}$ & $\begin{array}{c}\text { Barehull } \\
(\mathrm{kN})\end{array}$ & $\begin{array}{c}\text { Resistance } \\
\text { Stern wedge 1\%Lpp 40 } \\
(\mathrm{kN})\end{array}$ & $\begin{array}{c}\text { Difference } \\
(\%)\end{array}$ \\
\hline 1. & 12 & 0.2658 & 62.88 & 64.99 & $-3.4 \%$ \\
2. & 16 & 0.3545 & 96.72 & 95.45 & $1.3 \%$ \\
3. & 20 & 0.4431 & 157.17 & 153.98 & $2.0 \%$ \\
4. & 24 & 0.5317 & 215.38 & 211.35 & $1.9 \%$ \\
5. & 28 & 0.6203 & 266.42 & 261.23 & $1.9 \%$ \\
\hline
\end{tabular}


From the calculation of difference on the stern wedge $1 \% \operatorname{Lpp~} 4^{0}$ angle experienced additional resistance at 12 knots, which was originally 62.88 $\mathrm{kN}$, when using the stern wedge to $64.99 \mathrm{kN}$. However, at a speed of 16 knots, the resistance decreases by $1 \%$ up to 28 knots speed is reached.
Resistance decreased to $5.2 \mathrm{kN}$. The flow of the flow becomes slightly elongated and the direction of the flow becomes downward as the picture. A flow water at the stern there is a turbulance flow. It is therefore possible that when the vessel at low speed it becomes an additional resistance.

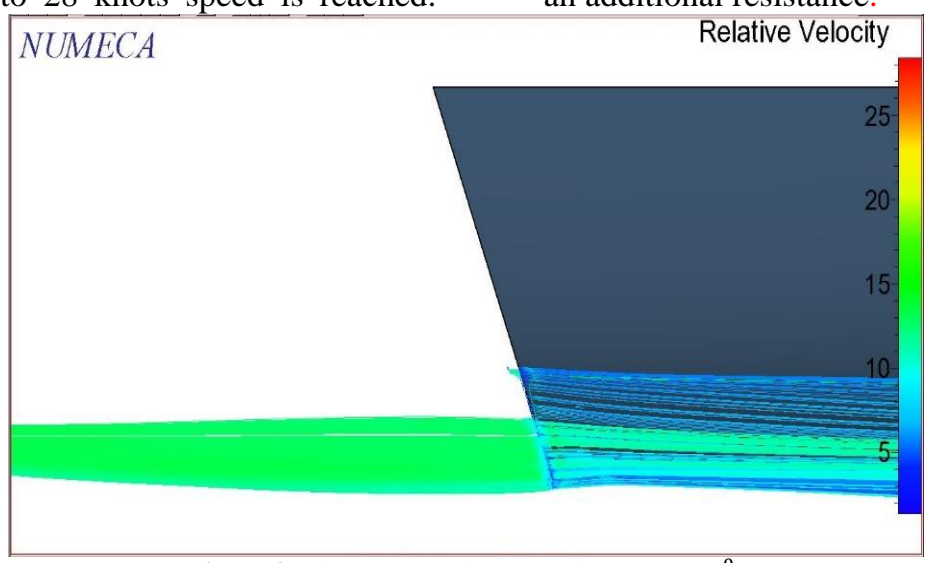

Figure 8. Flow pattern of stern wedge $1 \% \operatorname{Lpp} 4^{0}$

6. Resistance difference barehull with Stern wedge $1 \%$ Lpp $8^{0}$
Simulation of obstacles stern wedge $1 \%$ Lpp $8^{0}$ angle in get result as follows:

TABLE 6.

COMPARISON BAREHULL RESISTANCE WITH STERN WEDGE $1 \%$ LPP $8^{0}$

\begin{tabular}{cccccc}
\hline No & $\begin{array}{c}\text { Speed } \\
(\mathrm{knot})\end{array}$ & $\begin{array}{c}\text { Froude } \\
\text { Number }\end{array}$ & $\begin{array}{c}\text { Barehull } \\
(\mathrm{kN})\end{array}$ & $\begin{array}{c}\text { Resistance } \\
\text { Stern wedge 1\%Lpp 8 } \\
(\mathrm{kN})\end{array}$ & $\begin{array}{c}\text { Difference } \\
(\%)\end{array}$ \\
\hline 1 & 12 & 0.2658 & 62.88 & 68.92 & $-9.6 \%$ \\
2 & 16 & 0.3545 & 96.72 & 98.32 & $-1.7 \%$ \\
3 & 20 & 0.4431 & 157.17 & 158.03 & $-0.5 \%$ \\
4 & 24 & 0.5317 & 215.38 & 214.76 & $0.3 \%$ \\
5 & 28 & 0.6203 & 266.42 & 266.06 & $0.1 \%$ \\
\hline
\end{tabular}

Difference constraints due to their stern wedge $1 \%$ Lpp $8^{0}$ angle increased, the increase in speed of 12 knots at $6 \mathrm{kN}$ or $9.6 \%$. from figure simulation results and high flow wave patterns that occur when using a fast ship stern wedge at a speed of 8 knots 2:

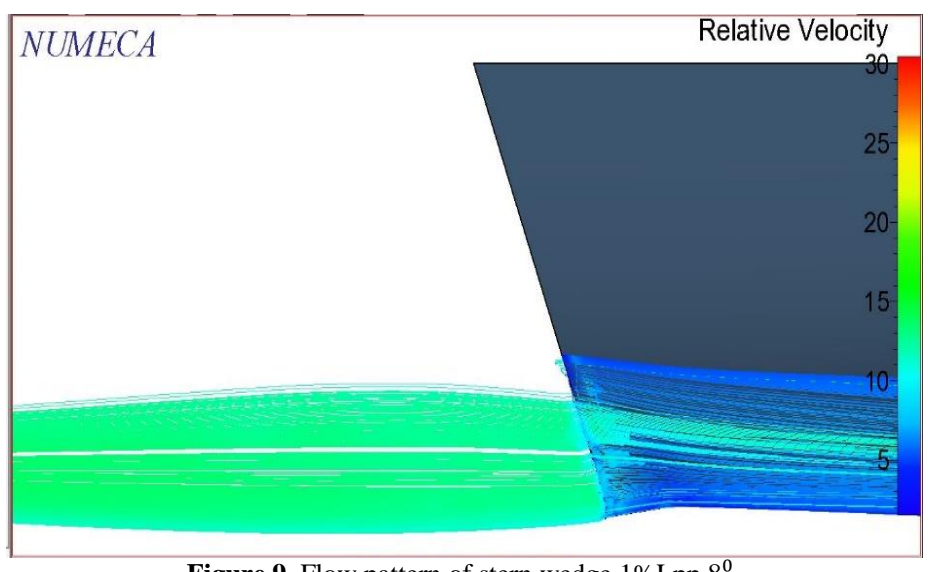

Figure 9. Flow pattern of stern wedge $1 \% \operatorname{Lpp} 8^{0}$

7. Resistance difference barehull with Stern wedge $1.5 \% \operatorname{Lpp} 4^{0}$
The result of simulation of barrier at stern wedge with Length $1.5 \% \mathrm{Lpp}$ and angle $4^{0}$, is as follows:

TABLE 7.

COMPARISON BAREHULL RESISTANCE WITH STERN WEDGE $1,5 \%$ LPP $4^{0}$

\begin{tabular}{lccccc}
\hline No & $\begin{array}{c}\text { Speed } \\
(\mathrm{knot})\end{array}$ & $\begin{array}{c}\text { Froude } \\
\text { Number }\end{array}$ & $\begin{array}{c}\text { Rarehull } \\
(\mathrm{kN})\end{array}$ & $\begin{array}{c}\text { Stern wedge } \\
4^{0} \\
(\mathrm{kN})\end{array}$ & $\begin{array}{c}\text { Difference } \\
(\%)\end{array}$ \\
\hline 1. & 12 & 0.2658 & 62.88 & 66.19 & $-5.3 \%$ \\
2. & 16 & 0.3545 & 96.72 & 96.55 & $0.2 \%$ \\
3. & 20 & 0.4431 & 157.17 & 155.67 & $1.0 \%$ \\
4. & 24 & 0.5317 & 215.38 & 212.46 & $1.4 \%$ \\
5. & 28 & 0.6203 & 266.42 & 262.60 & $1.4 \%$ \\
\hline
\end{tabular}


Difference constraints due to their stern wedge $1.5 \%$ Lpp $4^{0}$ increased resistance at speed of 12 knots, the increase amounted to $3.31 \mathrm{kN}$, or $5.3 \%$ of a ship without a stern wedge. There was decrease resistance at speed 16-28 knots, a decrease of 0.16 to $3.82 \mathrm{kN}$. In shape waves there is a change of the stern part that there is no stern wedge. The stern waveforms of the divergent wave and transverse wave are also changing. From before, stern wedge waveform becomes more smoth and deep wave height. Following is a simulation result of flow pattern and wave height at 28 knots speed:

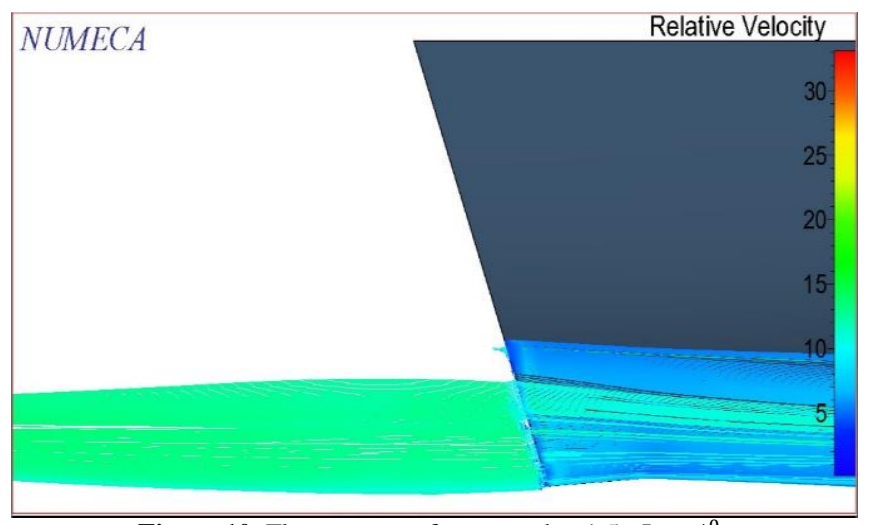

Figure 10. Flow pattern of stern wedge 1,5\% Lpp 4

8. Resistance difference Barehull with Stern Wedge $1.5 \% \operatorname{Lpp} 8^{0}$

Results of simulation stern wedge $1.5 \%$ angle $8 p$ Lpp, as follows:

TABLE 8.

COMPARISON BAREHULL RESISTANCE WITH STERN WEDGE 1,5\%LPP $8^{0}$

\begin{tabular}{|c|c|c|c|c|c|}
\hline No & $\begin{array}{l}\text { Speed } \\
\text { Knot }\end{array}$ & $\begin{array}{l}\text { Froude } \\
\text { Number }\end{array}$ & $\begin{array}{c}\text { Bare hull } \\
\mathrm{kN}\end{array}$ & $\begin{array}{l}\text { Resistance } \\
\text { Stern wedge } 1,5 \% \text { Lpp } 8^{0} \\
\text { kN }\end{array}$ & $\begin{array}{c}\text { Difference } \\
\%\end{array}$ \\
\hline 1 & 12 & 0.2658 & $\begin{array}{l}62.88 \\
\end{array}$ & 72.39 & $-15.1 \%$ \\
\hline 2 & 16 & 0.3545 & 96.72 & 101.69 & $-5.1 \%$ \\
\hline 3 & 20 & 0.4431 & 157.17 & 161.96 & $-3.1 \%$ \\
\hline 4 & 24 & 0.5317 & 215.38 & 219.52 & $-1.9 \%$ \\
\hline 5 & 28 & 0.6203 & 266.42 & 271.36 & $-1.9 \%$ \\
\hline
\end{tabular}

From the data calculation, the obstacles that occur due to the stern wedge $1.5 \% \mathrm{Lpp}$ angle $8^{0}$ has increased, $9.5 \mathrm{kN}$ at $12 \mathrm{knots}$. Enhancement resistance

occur at all speeds. The following is a simulation result of flow pattern and wave height at 28 knots speed:

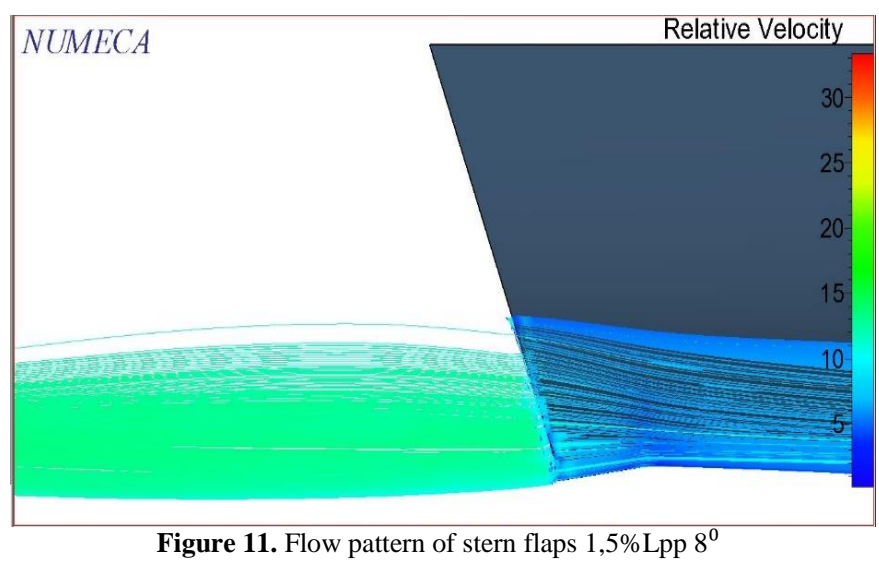

\section{Data Analisys}

Difference of Resistance value with the most optimum stern flaps Resistance that happen due to the addition of the experiments can be compared the difference in a graph. 


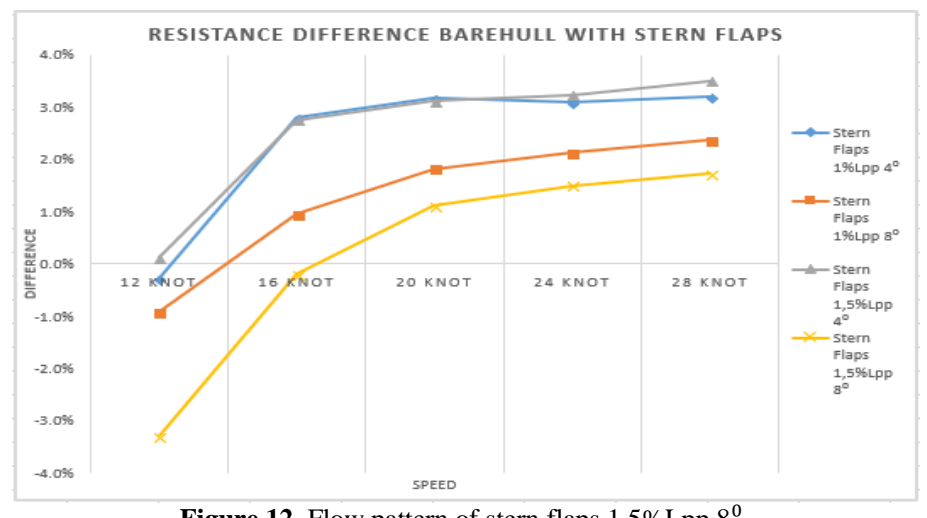

Figure 12. Flow pattern of stern flaps $1,5 \% \operatorname{Lpp} 8^{0}$

It was concluded that the stern flaps model which reduces the most optimum resistance is Stern Flaps $1.5 \% \mathrm{Lpp}$ and $4^{0}$ angle. In the model, resistance can be reduced by the addition of length on the stern of ship and the angle that is not deep. If the angle is deep, then the angle becomes the additional resistance of ship, as occurs on the Stern Flaps $1.5 \%$
Lpp and $8^{0}$ angle. Difference in resistance Value with the most optimum Stern Wedge that occurs due to the addition of stern wedge some of the above experiments can be compared in the difference in a graph. Here is a comparison chart of all stern wedge models.

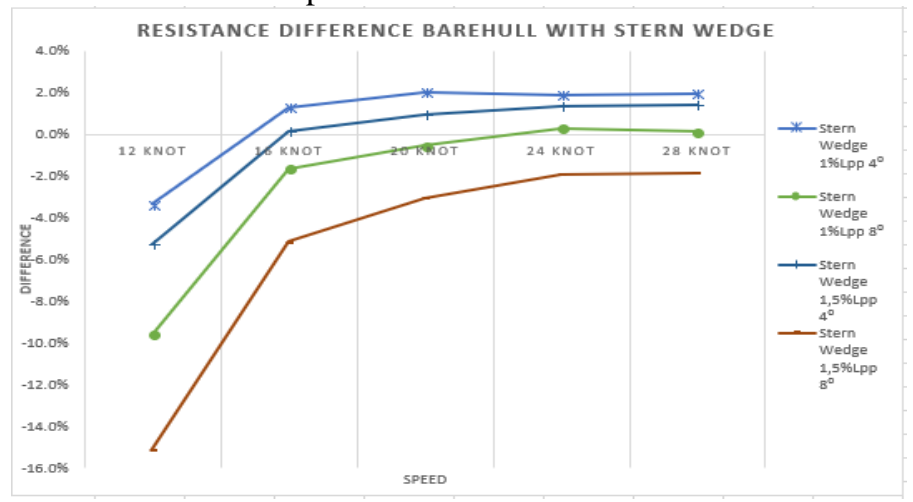

Figure 13. Comparison of resistance Barehull and Stern Wedge

From the graph, it was concluded that the stern wedge model that can reduce the most optimum resistance is Stern wedge $1 \% \mathrm{Lpp}$ and $4^{\circ}$ angle. Resistance decreases when speed is 16 - 28 knots. It means that the obstacles are reduced by the presence of aft with a not too deep angle. If it too deep, it becomes resistance of ship, as in Stern Wedge model $1.5 \%$ Lpp angle $8^{\circ}$.
D. The most optimally resistance Comparison (best)

Resistance threshold is value of the obstacle which decreases significantly from low to maximal speed. The value will be encountered if it has done repeatedly. In thesis has been done research by CFD method and can simulation results from 9 models with 5 variations speed. From 9 models, will selection 3 models that can reduce resistance optimally.

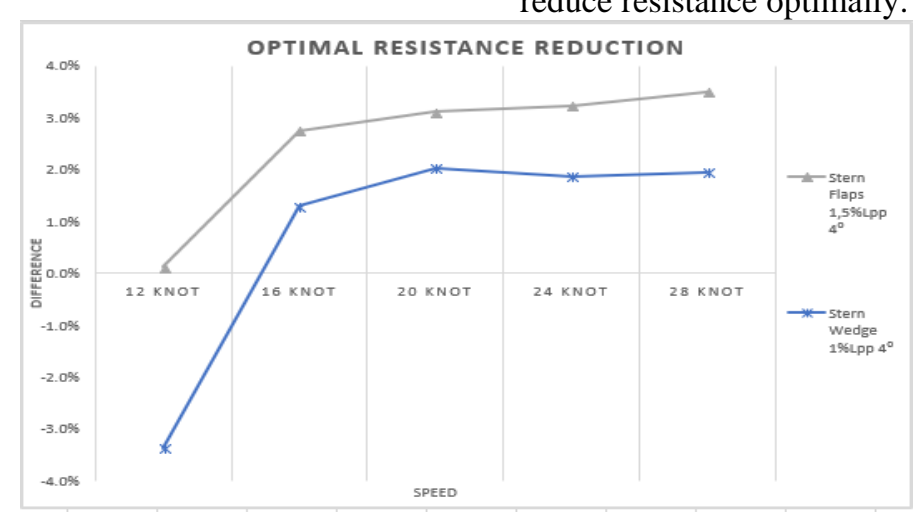

Figure 13. The most Optimal (best) resistance Comparison

The ratio of the comparison between the models shows the most optimal resistance is simulation of the stern flaps $1.5 \%$ angle Lpp $4^{0}$, and stern wedge $1 \%$ angle Lpp $4^{\circ}$. Of the two models have been compared, known from the simulation results with numeca software, that the value of the resistance is much reduced is when the ship using stern flaps. A decreasing resistance is in the range of $0.08-9.33 \mathrm{kN}$ at speed of $12-28$ knots. While the resistance that occur due to the wedge with $1 \% \mathrm{Lpp}$ and $4^{\circ}$ angle have increased the resistance at 12 knots, which was originally 62.88 $\mathrm{kN}$, when using the stern wedge to 64.99 . However, 
at a speed of 16 knots the resistance decreases by $1 \%$ and at 28 knots the resistance becomes $5.2 \mathrm{kN}$.

\section{CONCLUSION}

Based on simulations on fast boats about the difference of obstacles Stern Flaps and Stern Wedge , concluded :

1. There is an effect of ship resistance with the addition of Stern Flaps. with additions Stern Flaps resistance becomes reduced to $9.33 \mathrm{kN}$ at 28 knots. It occurs on a ship with Stern Flaps $1.5 \%$ Lpp angle $4^{0}$.

2. The influence of ship resistance with the addition of Stern Wedge. With the addition of Stern wedge shape the resistance value decreases $5.19 \mathrm{kN}$ at a speed of 28 knots. It happens on a ship with Stern Wedge $1 \%$ Lpp angle $4^{0}$. But on Stern Wedge the reduction is less optimum, because ifusing Stern Wedge decrease resistance do not happen when the ship drove at low speed.

3. From the simulation results obtained obstacle data indicating the optimum, desrease resistance there are boats with Stern Flaps $1.5 \%$ Lpp $4^{0}$ angle. decreas occur at low speeds up to high speed. So it can be concluded that the best Stern Flaps used are Stern Flaps $1.5 \%$ Lpp angle $4^{0}$.

4. Simulation results show that stern changes can change the pattern of water flow around the stern of the ship. But not all forms of stern able to reduce obstacles.

\section{REFERENCEs}

[1.] Harvald, Sv. AA. 1992. Resistance and Propulsion of Ship, Willey, New York.

[2.] Sid'qon, Habibie. 2015. Study of stern hullform of shallow draft vessel to increase ship performance. Master Thesis, Institut Teknologi Sepuluh Nopember, Surabaya.

[3.] Amiadji, A. Baidowi and A. Fauzi, 2018, The Effect of Boss Cap Fins to B - Series Propeller Performance With CFD Method, International Journal of Marine Engineering Innovation and Research, Vol. 2(4), Sep. 2018. 278-283

[4.] Maulana, Aktivano. 2017. Analisa Penambahan Stern Flap pada Kapal Hull Planing Chine Axe Bow Pengaruhnya Terhadap Tahanan Kapal. Fakultas Teknologi Kelautan-ITS, Surabaya.

[5.] Bojovic, Predrag and Sahoo, Prasanta K., 2011, Effect of Stern Wedge and Advanced Spray Rail System on Calm Water Resistance of High-Speed Displacement Hull Forms, ABS Americas, Australian Maritime College.

[6.] Karafiath, G., 1997. Stern Wedges and Stern Flaps for Improved Powering. Office of Naval Research Department of the Navy.

[7.] Dominic S. Cusanelli, 2011, Hydrodynamic and Supportive Structure for Gated Ship Sterns - Amphibious Ship Stern Flap, 11th International Conference on Fast Sea Transportation, Honolulu.

[8.] Omar Yaakob, Suhaili Shamsuddin \& Koh K King, 2004, Stern Flap For Resistance Reduction Of Planing Hull Craft: A Case Study With A Fast Crew Boat Model, Jurnal Teknologi, 41(A) Dis: 43-52

[9.] Karafiath, et.al, 2011,Stern Wedges and Stern Flaps for Improved Powering - U.S. Navy Experience, Society of Naval Architects and Marine Engineers.

[10.] Numeca International, 2014, Numeca Fine Open Manual Book, Belgium. 